\title{
Blockade of MCAM/CD146 impedes CNS infiltration of T cells over the choroid plexus
}

\author{
Johanna Breuer ${ }^{1}$, Eva Korpos ${ }^{2,3}$, Melanie-Jane Hannocks ${ }^{2,3}$, Tilman Schneider-Hohendorf ${ }^{1}$, Jian Song ${ }^{2,3}$, \\ Lisa Zondler ${ }^{4}$, Sebastian Herich ${ }^{1}$, Ken Flanagan ${ }^{5}$, Thomas Korn ${ }^{6,7}$, Alexander Zarbock ${ }^{4,3}$, Tanja Kuhlmann" \\ Lydia Sorokin ${ }^{2,3}$, Heinz Wiendl ${ }^{1,3}$ and Nicholas Schwab ${ }^{1 *}$
}

\begin{abstract}
Background: Very late antigen 4 (VLA-4; integrin a4 $\beta 1$ ) is critical for transmigration of T helper $\left(T_{H}\right) 1$ cells into the central nervous system (CNS) under inflammatory conditions such as multiple sclerosis (MS). We have previously shown that VLA-4 and melanoma cell adhesion molecule (MCAM) are important for trans-endothelial migration of human $T_{H} 17$ cells in vitro and here investigate their contribution to pathogenic CNS inflammation.

Methods: Antibody blockade of VLA-4 and MCAM is assessed in murine models of CNS inflammation in conjunction with conditional ablation of a4-integrin expression in T cells. Effects of VLA-4 and MCAM blockade on lymphocyte migration are further investigated in the human system via in vitro $T$ cell transmigration assays.

Results: Compared to the broad effects of VLA-4 blockade on encephalitogenic T cell migration over endothelial barriers, MCAM blockade impeded encephalitogenic T cell migration in murine models of MS that especially depend on CNS migration across the choroid plexus (CP). In transgenic mice lacking T cell a4-integrin expression (CD4:Itga $4^{-/-}$), MCAM blockade delayed disease onset. Migration of MCAM-expressing T cells through the CP into the CNS was restricted, where laminin 411 (composed of $a 4, \beta 1, \gamma 1$ chains), the proposed major ligand of MCAM, is detected in the endothelial basement membranes of murine CP tissue. This finding was translated to the human system; blockade of MCAM with a therapeutic antibody reduced in vitro transmigration of MCAM-expressing T cells across a human fibroblast-derived extracellular matrix layer and a brain-derived endothelial monolayer, both expressing laminin a4. Laminin a4 was further detected in situ in CP endothelial-basement membranes in MS patients' brain tissue.

Conclusions: Our findings suggest that MCAM-laminin 411 interactions facilitate trans-endothelial migration of MCAM-expressing T cells into the CNS, which seems to be highly relevant to migration via the CP and to potential future clinical applications in neuroinflammatory disorders.
\end{abstract}

Keywords: MCAM, VLA-4, CNS-migration, Choroid plexus, Laminin 411, EAE

\section{Background}

Multiple sclerosis (MS), a chronic disorder of the central nervous system (CNS), is characterized by inflammatory lesions at early disease stages that are caused by the infiltration of autoreactive immune cells into the CNS $[1,2]$. The inflammatory infiltrates, containing pathogenic $\mathrm{T}$ cells ( $\mathrm{T}$ helper $1\left(\mathrm{~T}_{\mathrm{H}} 1\right)$ and $\mathrm{T}_{\mathrm{H}} 17$ cells), lead to demyelination and neuronal degeneration resulting in serious physical disability [3, 4].

\footnotetext{
* Correspondence: nicholas.schwab@ukmuenster.de

${ }^{1}$ Clinic of Neurology with Institute of Translational Neurology, University of Münster, Albert-Schweitzer-Campus-1, Building A01, 48149 Münster, Germany Full list of author information is available at the end of the article
}

Immune cell infiltration from the periphery into the CNS, characteristic of the common relapsing-remitting form of MS (RRMS), has been successfully targeted by new therapies. In particular, the monoclonal antibody natalizumab, which recognizes the integrin $\alpha 4$ subunit of very late antigen-4 (VLA-4, integrin $\alpha 4 \beta 1, \mathrm{CD} 49 \mathrm{~d} /$ CD29), has proven highly effective in reducing disease progression by preventing leukocyte migration into the CNS $[5,6]$. VLA-4 plays a key role in the entry of encephalitogenic $\mathrm{T}$ cells into the CNS by mediating the initial rolling and adhesion steps of transmigration through interaction with its receptor, vascular cell adhesion molecule-1 (VCAM-1), expressed on

(C) The Author(s). 2018 Open Access This article is distributed under the terms of the Creative Commons Attribution 4.0 International License (http://creativecommons.org/licenses/by/4.0/), which permits unrestricted use, distribution, and 
endothelial cells of post-capillary venules upon inflammation [7]. Even though VLA-4 has been shown to play a crucial role in leukocyte trafficking over the blood-brain barrier (BBB), animal studies revealed that a subpopulation of $\mathrm{T}_{\mathrm{H}} 17$ cells, which represent a major pathogenic $\mathrm{T}$ cell population in murine experimental autoimmune encephalomyelitis (EAE) [8-10], can invade the CNS in a VLA-4 independent manner. Recent studies suggest that $\mathrm{T}_{\mathrm{H}} 17$ cells mainly rely on leukocyte function-associated molecule-1 (LFA-1) mediated firm adhesion to endothelial intercellular adhesion molecule-1 (ICAM-1) to penetrate the choroid plexus $(\mathrm{CP})$ and enter into the CNS parenchyma or the cerebrospinal fluid (CSF) space [11-13]. However, LFA-1 is primarily involved in the firm adhesion to endothelium and subsequent para-endothelial migration, and not in the initial rolling and adhesive steps [14]. This poses the question of how the initial adhesive steps are mediated in the encephalitogenic $T_{H} 17$ subpopulation and raises the possibility that different immune cell-adhesion receptor interactions are employed, depending on the route of entry into the brain and the cellular barrier involved. Three important barriers restrict access of circulating immune cells to the CNS parenchyma: the endothelial BBB in CNS post-capillary venules, the epithelial-cerebrospinal fluid barrier (BCSFB) at the $\mathrm{CP}$, and the arachnoidea formed by leptomeningeal cells [14-16].

Apart from LFA-1-ICAM-1-dependent penetration of the $\mathrm{CP}$ by $\mathrm{T}_{\mathrm{H}} 17$ cells, we have recently shown that adhesion of $T_{H} 17$ cells to an in vitro model of the BBB in the absence of VLA-4 involves melanoma cell adhesion molecule (MCAM; CD146) [17]. MCAM is an extracellular adhesion molecule broadly expressed on mesenchymally derived tissues [18]; in humans it has also been reported to be expressed on a subpopulation of IL-17-secreting $\mathrm{CD} 4^{+}$and $\mathrm{CD} 8^{+} \mathrm{T}$ cells $\left(\mathrm{T}_{\mathrm{H}} 17\right.$ and Tc17 cells, respectively) [18-25]. EAE experiments performed in endothelial MCAM knockout mice have shown reduced disease severity and reduced $\mathrm{T}_{\mathrm{H}} 17$ infiltration into the CNS, supporting a role for this molecule in the entry of encephalitogenic $T$ cells into the brain [26]. Laminin 411 (composed of $\alpha 4, \beta 1$, and $\gamma 1$ chains), a major component of endothelial basement membranes [27], has been identified as a ligand for MCAM, and MCAM-laminin 411 interactions have been proposed to facilitate penetration of the BBB [22]. However, whether MCAM can contribute to $\mathrm{T}_{\mathrm{H}} 17$ penetration of other CNS barriers remains unclear.

The focus of the current study was, therefore, to elucidate the pathogenic relevance of MCAM compared to VLA-4 in CNS inflammation in vivo by using different murine models of MS (active and spontaneous experimental autoimmune encephalitis (EAE)). Using antibody- mediated blocking of VLA-4 and/or MCAM and T cell-specific ablation of $\alpha 4$-integrin expression, we show here that VLA-4 blockade abrogates the encephalitogenic potential of $\mathrm{T}$ cells in a wide-ranging way by blocking migration over endothelial barriers, whereas MCAM targeting primarily restricts migration of $\mathrm{T}_{\mathrm{H}} 17$ cells over the $\mathrm{CP}$ into the CNS by inhibiting MCAM-laminin $\alpha 4$ interactions at the endothelial CP layer.

\section{Methods \\ Mice}

Eight- to 10-week-old C57BL/6 mice were purchased from Harlan Laboratories (Horst, Netherlands). CD4-cre mice were crossed with integrin Itga $4^{\text {flox/flox }}$ mice as previously described $[12,28]$ to generate mice lacking integrin $\alpha 4 \beta 1$ specifically on $\mathrm{T}$ cells $\left(\mathrm{CD} 4:: \operatorname{Itga4^{-1-}}{ }^{-}\right.$). Double-transgenic mice $\left(\mathrm{TCR}^{\mathrm{MOG}} \times \mathrm{IgH}^{\mathrm{MOG}}\right.$ mice or OSE/DEVIC mice) expressing $\mathrm{T}$ - and $\mathrm{B}$-cell receptors that recognize the same myelin protein $\left(\mathrm{MOG}_{35-55}\right)$ were generated by crossbreeding transgenic mice carrying either a $\mathrm{MOG}_{35-55}$-specific $\mathrm{T}$ cell receptor $\left(\mathrm{TCR}^{\mathrm{MOG}}\right.$ also referred to as $2 \mathrm{D} 2$ [29])

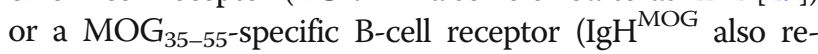
ferred to as Th [30]) as described previously [31, 32].

All animal experiments were approved by and conducted in accordance with the laws and regulations of the regulatory authorities for animal care and scientific use in North Rhine-Westphalia, Germany (TVA-number 84-02.04.2014.A075).

\section{Induction of EAE}

EAE was induced in 6- to 8-week-old CD4::Itga4 ${ }^{-1-}$ mice by subcutaneous injection of $200 \mu \mathrm{g} \mathrm{MOG}_{35-55}$ peptide (MEVGWYRSPFSRVVHLYRNGK; Charité, Berlin, Germany) emulsified in CFA containing $200 \mu \mathrm{g}$ Mycobacterium tuberculosis H37RA (Difco, MI, USA). Pertussis toxin (400 ng; Alexis, San Diego, CA, USA) in $200 \mu \mathrm{l}$ PBS was injected intraperitoneally (i.p.) on the day of immunization (day 0) and 2 days later. Disease severity was scored daily on a scale from 0 to 10 as previously described [33]: grade 0 , no abnormality; grade 1 , limp tail tip; grade 2, limp tail; grade 3, moderate hindlimb weakness; grade 4, complete hindlimb weakness; grade 5, mild paraparesis; grade 6, paraparesis; grade 7 , heavy paraparesis; grade 8 , tetraparesis; grade 9 , quadriplegia or premoribund state; grade 10, death (experimental autoimmune neuritis (EAN) score). Animals were scored in a blinded fashion by two independent observers. Disease onset was defined as a score greater than or equal to 1 .

\section{Antibody treatment for in vivo blocking}

The blocking antibodies anti-mMCAM (clone 15) (described in [22]) and $\alpha 4$ integrin neutralizing antibody (clone: PS/2, BioXCell, New Hampshire, USA) as well as 
the appropriate isotype control antibodies (rat IgG1, clone: HRPN and rat IgG2b, clone: LTF-2; both BioXCell) were used at a concentration of $10 \mathrm{mg} / \mathrm{kg}$ body weight. Mice were treated every other day with i.p. injections of the respective antibody from the indicated day on.

\section{Cell preparation and flow cytometry}

Single-cell suspensions of mouse spleens and peripheral blood were prepared as described previously [33]. Mononuclear cells were isolated from spinal cord and brain by Percoll gradient [33] and cells were stained for $30 \mathrm{~min}$ at $4{ }^{\circ} \mathrm{C}$ with fluorescence-labeled mAbs in PBS containing $0.1 \%$ BSA. The following antibodies were used for the detection of cell surface markers: anti-MCAM (clone: ME-9F1), anti-CD3 (clone: 17A2), anti-CD4 (clone: RM4-5), anti-NK1.1 (clone: PK136) (all from BioLegend, Fell, Germany). Cells were assessed on a Gallios ${ }^{\mathrm{Tm}}$ (Beckman Coulter, Krefeld, Germany) and analyzed using Kaluza software (Beckman Coulter).

\section{Adoptive cell-transfer and staining of CP explants}

For adoptive transfer experiments, splenocytes of 2D2 mice were isolated and cultured under MCAM polarization conditions as described previously [22]. Briefly, cells were cultured for 5 days in RPMI (1640) supplemented with $10 \%$ heat-inactivated fetal calf serum (FCS), 1\% penicillin-streptomycin, 1\% L-glutamine, and $50 \mu \mathrm{M}$ 2-mercaptoethanol (2-ME) in the presence of $10 \mu \mathrm{g} / \mathrm{ml} \mathrm{MOG}_{35-55}$ peptide, $5 \mu \mathrm{g} / \mathrm{ml}$ anti-IFN $\gamma$ (clone: XMG1.2), $0.5 \mu \mathrm{g} / \mathrm{ml}$ anti-IL-4 (clone: 11B11, both eBioscience), $5 \mathrm{ng} / \mathrm{ml}$ human TGF $\beta$, and $20 \mathrm{ng} / \mathrm{ml}$ murine IL-23 (both R\&D systems, Wiesbaden, Germany). CD4 ${ }^{+} \mathrm{T}$ cells were enriched by negative selection using MACS (Miltenyi Biotec, Bergisch Gladbach, Germany), labeled with $1 \mu \mathrm{M}$ CellTracker ${ }^{\text {mm }}$ Green CMFDA Dye (ThermoFisher, Waltham, MA, USA) and adoptively transferred into C57BL/6 recipient mice $\left(2.4 \times 10^{6} \mathrm{CD}^{+} \mathrm{T}\right.$ cells per mouse in $100 \mu \mathrm{l}$ PBS) by i.v. injection. On days 2 and 5 after adoptive transfer choroid plexus explants were stained as follows. After transferring the explanted choroid plexus epithelia on glass slides, PBS $+0.3 \%$ tween 20 was applied for $5 \mathrm{~min}$ followed by two washing steps in PBS for 5 min. CP explants were fixed applying PBS $+2.2 \%$ PFA $+2 \%$ glucose $+0.02 \%$ sodium azide for $20 \mathrm{~min}$ at RT, rinsed in PBS, and additionally fixed using $100 \%$ methanol for $6 \mathrm{~min}$. After two subsequent washes in PBS for $5 \mathrm{~min}$, unspecific binding was blocked by applying PBS $+0.3 \%$ tween $20+10 \%$ normal goat serum for $30 \mathrm{~min}$ at RT and then stained with anti-laminin $\alpha 4$ (clone 377; 1:1000, rabbit anti mouse; [34]) in PBS $+0.3 \%$ tween 20 for $2 \mathrm{~h}$ at RT. Subsequently, the stained CP explants were washed twice for $5 \mathrm{~min}$ in PBS and stained using a secondary goat anti-rabbit antibody (1:100; Alexa fluor 568; Life Technologies) for $1 \mathrm{~h}$ at RT. After another washing series in PBS, cell nuclei were stained using DAPI $(1 \mu \mathrm{g} /$ $\mathrm{ml}$ ) in PBS for $5 \mathrm{~min}$ at RT, washed in PBS again, and mounted in fluorescent mounting medium (Dako).

\section{Cell culture and transmigration assays}

Fibroblasts originated from primary human choroid plexus epithelial cells (labeled as HCPEpiC) that were purchased from ScienCell Research Laboratories (Carlsbad, CA, USA) and were cultured in Epithelial Cell Medium (EpiCM) supplemented with 2\% fetal bovine serum (FBS; ProVitro, Berlin, Germany) on poly-L-lysine $\left(2 \mu \mathrm{g} / \mathrm{cm}^{2}\right.$; ScienCell Research Laboratories). Cultured cells were characterized by real-time quantitative PCR for expression of endothelial and epithelial markers as well as expression of laminin $\alpha 4$.

Primary human brain microvascular endothelial cells (HBMEC) were obtained from Pelobiotech $\mathrm{GmbH}$ (Planegg, Germany) and maintained in microvascular endothelial cell growth medium supplemented with FBS and endothelial cell growth factor (ECGF) (ProVitro) on fibronectin (Pelobiotech) as previously described [35]. Where indicated, HBMEC were treated with TNFa (500 U/ml; R\&D systems) for $16 \mathrm{~h}$. For transmigration assays, fibroblasts originating from HCPEpiC $\left(1 \times 10^{5}\right.$ cells) or HBMEC $\left(1 \times 10^{5}\right.$ cells $)$ were seeded on poly-Llysine or fibronectin-coated membranes of Transwell inserts $(6.5 \mathrm{~mm}$ Transwells Pore Polyester Membrane Insert; pore size $=3.0 \mu \mathrm{m}$; Corning, Lowell, MA, USA) and grown to confluency. $\mathrm{CD} 4^{+} \mathrm{T}$ cells were purified from whole blood of healthy donors (HD) using RosetteSep $\mathrm{CD}^{+}{ }^{+} \mathrm{T}$ cell enrichment cocktail (StemCell Technologies, Vancouver, BC, Canada). $2 \times 10^{5} \mathrm{CD}^{+}$cells were subsequently transferred to the endothelial cell layer and were allowed to migrate in RPMI medium supplemented with 2\% B27 (Gibco, Eggenstein, Germany) as previously described [36]. Transmigrated cells were collected from the lower chamber after an incubation time of $4 \mathrm{~h}$. CD4 $4^{+}$ $\mathrm{T}$ cells from within the fibroblastic layer were obtained by incubating the cell layer for $10 \mathrm{~min}$ at $37{ }^{\circ} \mathrm{C}$ with Accutase (Sigma-Aldrich, Taufkirchen, Germany) and cells were detached by rinsing with PBS. For quantification, Calibrite beads (BD Biosciences, Heidelberg, Germany) were added prior to harvesting the cells. The relative cell numbers were determined by flow cytometry and migrated cells were stained with anti-MCAM (clone: P1H12; BD Pharmingen, Franklin Lakes, NJ, USA), anti-CD4 (clone: OKT4), anti-CD11a (clone: HI111), anti-CD49d (clone: 9F10), anti-CD62L (clone: DREG56), and anti-CD45RA (clone: HI100) (all from BioLegend, Fell, Germany).

\section{Blocking antibodies for transmigration assays}

The blocking antibodies anti-VLA4 (anti-CD49d/natalizumab, Tysabri; Biogen Idec, Cambridge, MA, USA) and 
anti-MCAM (clone PRX003; Prothena Biosciences Inc., Dublin, Ireland) were used at a concentration of $10 \mu \mathrm{g} /$ $\mathrm{ml}$. CD4 ${ }^{+}$lymphocytes were pre-incubated for $30 \mathrm{~min}$ with the antibodies diluted in PBS before washing out of the blocking antibodies and application to the transmigration assays.

\section{Real-time quantitative PCR}

RNA was extracted from confluent monolayers of HCPEpiC-derived fibroblasts or HBMEC using TRIzol reagent (Invitrogen). cDNA was synthesized from $1 \mu \mathrm{g}$ of total RNA using a standard protocol with random hexamer primers (ThermoScientifc). Real-time qPCR was performed in a StepOnePlus cycler (Applied Biosystems, Darmstadt, Germany) employing endogen control primers for 18sRNA as well as a TaqMan Gene Expression Assays specific for human laminin $\alpha 4$, cytokeratin 18, VE-cadherin, vimentin, or PECAM1 (Applied Biosystems, Darmstadt, Germany).

\section{Immunofluorescence staining}

For immunofluorescence studies, 4- $\mu$ m-thick formalinfixed paraffin embedded (FFPE) murine brain sections were stained for MCAM (CD146, rabbit monoclonal IgG, clone: EPR3208; Abcam, Cambridge, UK). An amplification with TSA Plus Biotin kit (PerkinElmer, Waltham, USA) was performed according to the manufacturer's instructions. As secondary antibodies goatanti-rabbit-HRP (IgG; LifeTechnologies, Carlsbad, USA) and streptavidin AlexaFluor488 conjugate (Invitrogen, Carlsbad, USA) were used. Sections were mounted in Gold antifade containing 4',6-diamidino-2-phenylindole (DAPI, Invitrogen). Slides were analyzed on a BioRevo microscope (BZ-9000, Keyence, Osaka, Japan) using the BZ-II Analyzer software.

Six- $\mu \mathrm{m}$-thick cryosections of murine brain tissue were fixed with methanol and were stained for laminin $\alpha 4$ (clone 377b [37]), MECA32 antigen [38], and plectin (Progen, Heidelberg, Germany).

For human CNS tissue, autopsy material from subjects with MS was obtained from the Netherlands Brain Bank (NBB). Immunofluorescence stainings were performed on $10 \mu \mathrm{m}$ cryosections and paraformaldehyde-fixed confluent monolayers of fibroblasts (derived from primary HCPEpiC) with a monoclonal anti-human laminin $\alpha 4$ antibody (clone 3D12 [39]) and an AlexaFluor488-labeled goatanti-mouse secondary antibody. In case of the fibroblastic monolayers, an amplification step with TSA Plus Biotin kit (PerkinElmer, Waltham, MA, USA) was performed according to the manufacturer's instructions. Tissues were analyzed using a Zeiss LSM700 confocal microscope. Images were analyzed using Volocity 6.3 software (ImproVision).

\section{Study approval}

Studies on human samples were approved by the local ethics committee (University of Muenster: Ethik-Kommission der Ärztekammer Westfalen-Lippe und der Medizinischen Fakultät der Westfälischen Wilhelms-Universität, registration number: 2010-245-f-S). All experiments were performed according to the Declaration of Helsinki.

\section{Statistical analysis}

All values are presented as mean \pm standard error of the mean (SEM). Statistical significance was determined using Student's $t$ test in the case of normally distributed data; otherwise, a Mann-Whitney test was performed. For comparisons between data of $\mathrm{CD}^{+}$subpopulations from the same donor, the paired Student's $t$ test was used. The two-way ANOVA followed by Bonferroni post-test was applied for EAE experiments. $P$ values were considered significant if $<0.05$ in all cases. Statistical analyses were carried out using Prism (Version 5, GraphPad, San Diego, CA, USA).

\section{Results and discussion}

MCAM blockade delays EAE disease onset in T cell-specific integrin a4 knockout mice (CD4::Itga ${ }^{-/}$)

To investigate whether encephalitogenic $\mathrm{CD} 4^{+} \mathrm{T}$ cells without functionally active VLA-4 can employ MCAM to migrate into the CNS, we induced EAE in transgenic mice lacking $\alpha 4$-integrin expression on $\mathrm{T}$ cells $\left(\mathrm{CD} 4: \operatorname{Itga4}^{-/-}\right)$in the presence or absence of a functionblocking antibody to MCAM. MOG ${ }_{35-55}$ immunized CD4::Itga $4^{-1-}$ mice developed a mild and clinically atypical EAE, as previously reported [12] (Fig. 1a). Application of anti-MCAM to CD4::Itga4 ${ }^{-1-}$ mice every second day after $\mathrm{MOG}_{35-55}$ immunization commencing on day 0 resulted in a delay in disease onset (Fig. 1a, b and Table 1), but no change in disease severity. This suggests that in the absence of $\alpha 4$-integrin, MCAM blocking delays but does not completely prevent $\mathrm{CD}^{+} \mathrm{T}_{\mathrm{H}} 17$ entry into the CNS parenchyma. Former studies have shown that the chemokine receptor CCR6, which like MCAM is selectively upregulated in polarized murine $\mathrm{T}_{\mathrm{H}} 17$ cells $[10,22]$, is essential for CNS trafficking of $T_{H} 17$ cells to the CP. CCR6 ${ }^{+} \mathrm{T}_{\mathrm{H}} 17^{+}$cells are considered to represent the first wave of leukocyte infiltration required for the subsequent recruitment of other inflammatory cells $\left(\mathrm{T}_{\mathrm{H}} 1\right.$ cells) across post-capillary venules and induction of disease symptoms [10]. $T_{H} 17$ cells are further able to access the CNS parenchyma independently of VLA-4 and $\mathrm{MOG}_{35-55}$ immunized mice lacking $\alpha 4$-integrin expression on $\mathrm{T}$ cells $\left(\mathrm{CD} 4:\right.$ Itga $\left.^{-/-}\right)$exhibit marked immune cell infiltration within the plexus epithelium [12], indicating that in the absence of $\alpha 4$-integrin encephalitogenic $T$ cells are recruited via the choroid plexus into the CNS. These findings and the observed delay in EAE 

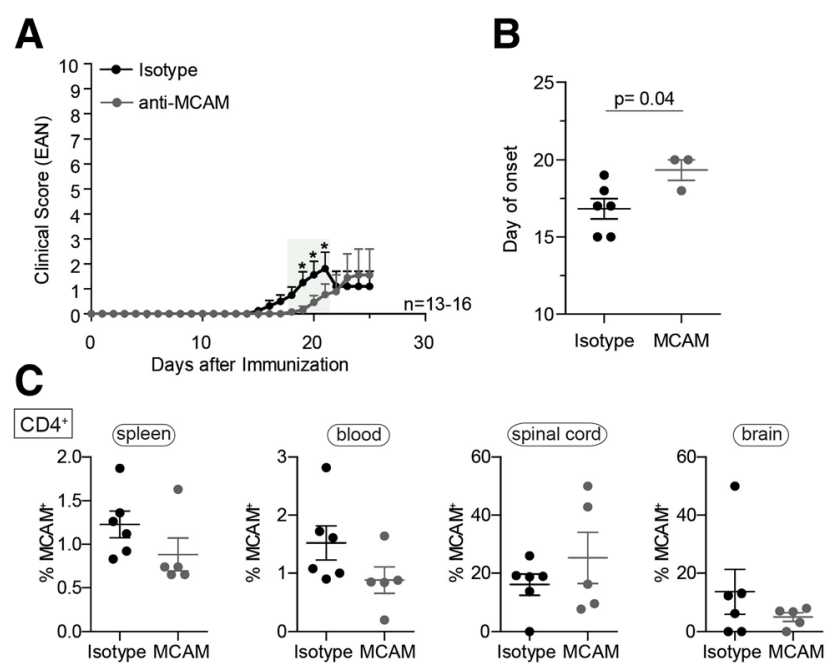

D

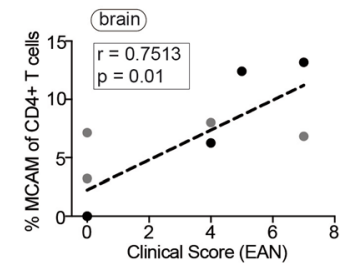

E
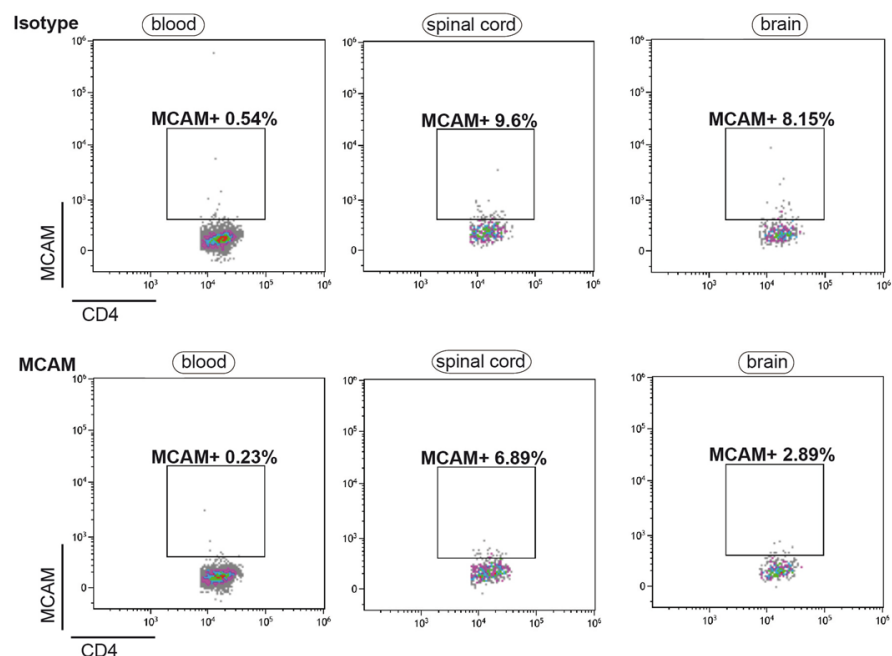

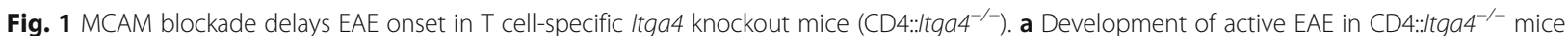
treated every other day after $\mathrm{MOG}_{35-55}$ immunization with anti-MCAM (clone 15) neutralizing antibody or isotype control antibody. Mean clinical EAN scores \pm SEM of three independent experiments over time are shown; ${ }^{*} P<0.05$; green highlighted areas: $P<0.1$ (b) The average day of disease onset, defined as the first day with a score greater than or equal to 1 , is shown as mean \pm SEM. Percentages of MCAM CD4 ${ }^{+}$ cells (c) isolated from the spleen, blood, spinal cord, and brain of isotype control or anti-MCAM-treated mice were quantified by flow cytometry on day 22 post $\mathrm{MOG}_{35-55}$ immunization. Correlation analyses between the clinical score (EAN) and percentages of MCAM-expressing CD4 ${ }^{+}$ T cells (d) in brains of isotype control (black dots) and anti-MCAM-treated mice (gray dots) on day 22 post immunization shows a positive correlation for $C D 4^{+} T$ cells (Spearman $r=0.7513 ; P=0.01$ ). e Representative flow cytometric analyses of $\mathrm{MCAM}^{+} \mathrm{CD}^{+} \mathrm{T}$ cells are shown for isotype control (upper panel) or anti-MCAM-treated mice (lower panel)

onset upon MCAM blockade suggest that, besides CCR6, MCAM might be crucial for the initial infiltration of encephalitogenic $\mathrm{T}_{\mathrm{H}} 17$ cells via the CP. Further, our recent observation of a specific accumulation of MCAM-expressing lymphocytes in the CSF of patients with MS that are under long-term natalizumab therapy (VLA-4 blockade) [17] suggests also that MCAM-expressing lymphocytes migrate over the $\mathrm{CP}$ into the CNS.

Blockade of MCAM might possibly impact migration into the CNS via blocking of endothelial MCAM, as entry of encephalitogenic $\mathrm{T}$ cells into the brain is reduced in endothelial MCAM knockout mice [26]; however, flow cytometry performed on day 22 post immunization with an anti-mMCAM, antibody recognizing an epitope distinct from the therapeutic antibody, showed that administration of the MCAM neutralizing antibody resulted in lower expression of MCAM on natural killer (NK) cells (Additional file 1: Figure S1a) and CD4 $4^{+} \mathrm{T}$ cells both in the periphery and the CNS (quantification is shown in Fig. 1c and representative flow cytometric analysis in Fig. 1e), suggesting 
Table 1 Summary of EAE incidence, onset, and maximum disease severity in different murine models of MS upon antibody mediated blocking of VLA-4, MCAM, or VLA-4 and MCAM

\begin{tabular}{|c|c|c|c|c|}
\hline Mouse & Treatment & Incidence & $\begin{array}{l}\text { Age (days)/day } \\
\text { of onset }\end{array}$ & $\begin{array}{l}\text { Cumulative } \\
\text { score }\end{array}$ \\
\hline $\begin{array}{l}\text { Integrin } \\
a 4^{-l-}\end{array}$ & Anti-MCAM & $\begin{array}{l}3 / 13 \\
(23 \%)\end{array}$ & $19.3 \pm 0.66$ & $0.21 \pm 0.12$ \\
\hline $\begin{array}{l}\text { Integrin } \\
a 4^{-l-}\end{array}$ & Isotype (MCAM) & $\begin{array}{l}6 / 16 \\
(38 \%)\end{array}$ & $16.8 \pm 0.65$ & $0.38 \pm 0.14$ \\
\hline Devic & Anti-VLA-4 & 1/11 (9\%) & $39 \pm 0$ & $0.01 \pm 0.01$ \\
\hline Devic & Isotype (VLA-4) & $\begin{array}{l}7 / 11 \\
(64 \%)\end{array}$ & $33.7 \pm 1.5$ & $0.58 \pm 0.16$ \\
\hline Devic & Anti-MCAM & $\begin{array}{l}9 / 22 \\
(41 \%)\end{array}$ & $34.3 \pm 1.6$ & $0.65 \pm 0.19$ \\
\hline Devic & Isotype (MCAM) & $\begin{array}{l}12 / 21 \\
(57 \%)\end{array}$ & $36.1 \pm 1.4$ & $0.79 \pm 0.19$ \\
\hline Devic & $\begin{array}{l}\text { Anti-VLA-4/ } \\
\text { MCAM }\end{array}$ & $\begin{array}{l}2 / 11 \\
(18 \%)\end{array}$ & $35.5 \pm 3.5$ & $0.09 \pm 0.07$ \\
\hline Devic & $\begin{array}{l}\text { Isotype (VLA-4/ } \\
\text { MCAM) }\end{array}$ & $\begin{array}{l}9 / 11 \\
(82 \%)\end{array}$ & $30 \pm 1.7$ & $1.54 \pm 0.09$ \\
\hline
\end{tabular}

The age/day of onset and the cumulative score are means \pm SEM

shedding or downregulation of MCAM on peripheral immune cells.

In mice, contrary to humans, MCAM is strongly expressed on NK cells [40], which might be a reason for the more pronounced downregulation in the percentages of $\mathrm{MCAM}^{+} \mathrm{NK}$ cells compared to the slight effect on $\mathrm{MCAM}^{+} \mathrm{T}$ cells. In CD4::Itga4 ${ }^{-/-}$mice-independent of the treatment, percentages of MCAM-expressing $\mathrm{CD}_{4}^{+}$ cells in the brain correlated with the clinical score (Spearman $r=0.7513 ; P=0.01$ ) (Fig. 1d), whereas MCAM-expressing NK cell proportions in the brain did not correlate with clinical score (Spearman $r=-0.4427$; $P=0.2$ ) (Additional file 1: Figure $\mathrm{S} 1 \mathrm{~b}$ ), indicating that the severity of EAE depends on the amount of $\mathrm{MCAM}^{+}$ $\mathrm{CD}^{+}{ }^{+} \mathrm{T}$ cells in the brain. As $\mathrm{CD} 4^{+} \mathrm{T}$ cells are the primary pathogenic $\mathrm{T}$ cells in EAE [41], this suggests that antibody blocking of MCAM affects either MCAM-expressing $\mathrm{T}_{\mathrm{H}} 17$ cell numbers in the periphery or their entry into the CNS and, thereby, EAE induction.

\section{Blockade of VLA-4 and MCAM in a spontaneous mouse model of MS ("Devic" mice)}

To assess whether anti-MCAM effects are specific to $\mathrm{T}_{\mathrm{H}} 17$ versus $\mathrm{T}_{\mathrm{H}} 1$-induced inflammation, we utilized a spontaneous mouse model of MS ("Devic" mice), which shows largely optic nerve and spinal cord leukocyte infiltration and is mainly characterized by a $\mathrm{T}_{\mathrm{H}} 1$ cytokine profile [31, 32, 42]. Devic mice are a double-transgenic mouse strain, expressing $\mathrm{T}$ and $\mathrm{B}$ cell receptors that recognize the same autoantigen (MOG), in which around $50 \%$ of the double-transgenic offspring spontaneously develop a paralytic disease reminiscent of a subset of neuromyelitis optica patients. Devic mice were treated every second day from day 16 after birth with either anti-VLA4, anti-MCAM, or both antibodies; control mice were treated with the appropriate isotype control antibodies. VLA-4 blockade largely protected mice from the development of paralytic disease (Fig. 2a and Table 1), whereas blockade of MCAM resulted in reduced disease incidence and severity (Fig. $2 b$ and Table 1). Blockade of both VLA-4 and MCAM did not show an additive effect compared to VLA-4 blockade alone (Fig. 2c and Table 1). These results are consistent with the reported high expression of VLA- 4 on $\mathrm{T}_{\mathrm{H}} 1$ cells and the comparatively low VLA-4 levels on MCAM ${ }^{\text {high }}$ $\mathrm{T}_{\mathrm{H}} 17$ cells $[12,22]$. In addition, the data suggest that the effects of anti-MCAM treatment are most pronounced in $\mathrm{T}_{\mathrm{H}} 17$-mediated EAE and therefore affect $\mathrm{T}_{\mathrm{H}} 17$ trafficking to the brain. Previous experiments employing murine models of MS with encephalitogenic T cells expressing VLA-4 showed that administration of a MCAM blocking antibody affected disease progression during remission [22-24]. However, mice with Devic's disease normally do not enter remission, which could explain why we did not observe effects of the MCAM treatment in the late stage of the disease.

In order to corroborate the influence of MCAM in CNS inflammation in the Devic model, we performed histological analyses of the $\mathrm{CP}$ tissue to investigate whether MCAM blockade might impact migration into the CNS via blocking of endothelial MCAM. However, endothelial MCAM expressing cells could easily be detected in the $\mathrm{CP}$ tissue of mice treated with anti-MCAM blocking antibody or with a synergistic blockade of MCAM and VLA-4 (Fig. 2d), suggesting that this anti-MCAM neutralizing antibody does not have any impact on endothelial MCAM and acts on peripheral immune cells.

To assess the relevance of MCAM expression on $\mathrm{T}$ cells for their transmigration across the $\mathrm{CP}$, we performed histological stainings of laminin $\alpha 4$, the proposed major ligand of MCAM, in murine CP tissue. Double staining of $\mathrm{CP}$ tissue from healthy control mice for endothelial or epithelial markers together with the MCAM ligand laminin $\alpha 4$ revealed laminin $\alpha 4$ staining exclusively in association with the MECA32 $2^{+}$endothelial cells of the CP (Fig. 3a) located between the plectin ${ }^{+}$epithelial cell layers (Fig. 3b) [43, 44]. Blockade of MCAM might therefore ameliorate CNS inflammation by preventing migration of MCAM expressing cells across the endothelial CP layer on their way into the CNS.

In a proof-of-concept experiment, we transferred fluorescently labeled myelin oligodendrocyte glycoproteinspecific TCR-transgenic T cells (2D2 T cells), differentiated in vitro with a protocol that induces high percentages of MCAM expressing cells [22], into C57BL/6 


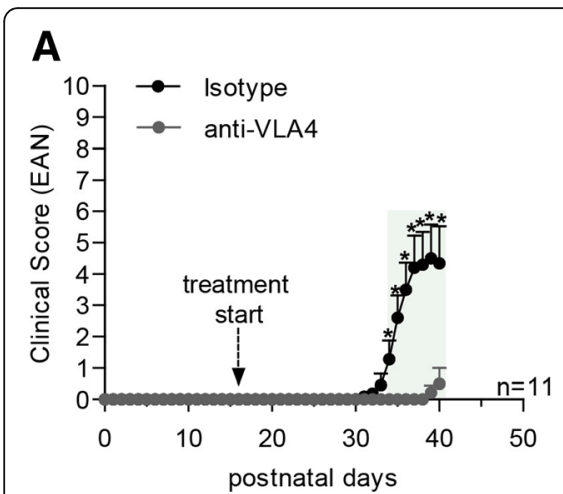

D

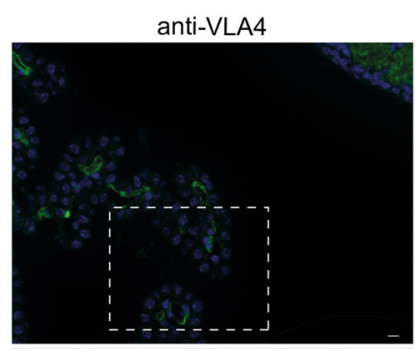

B

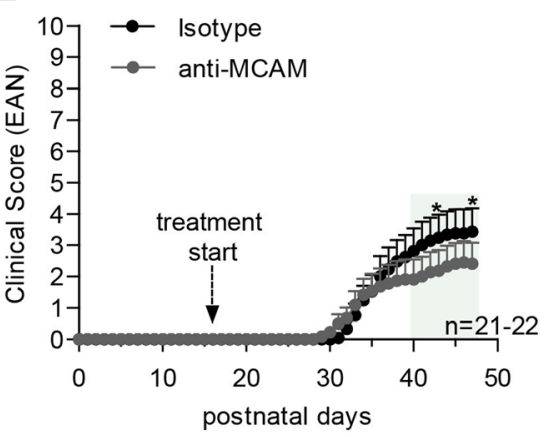

C
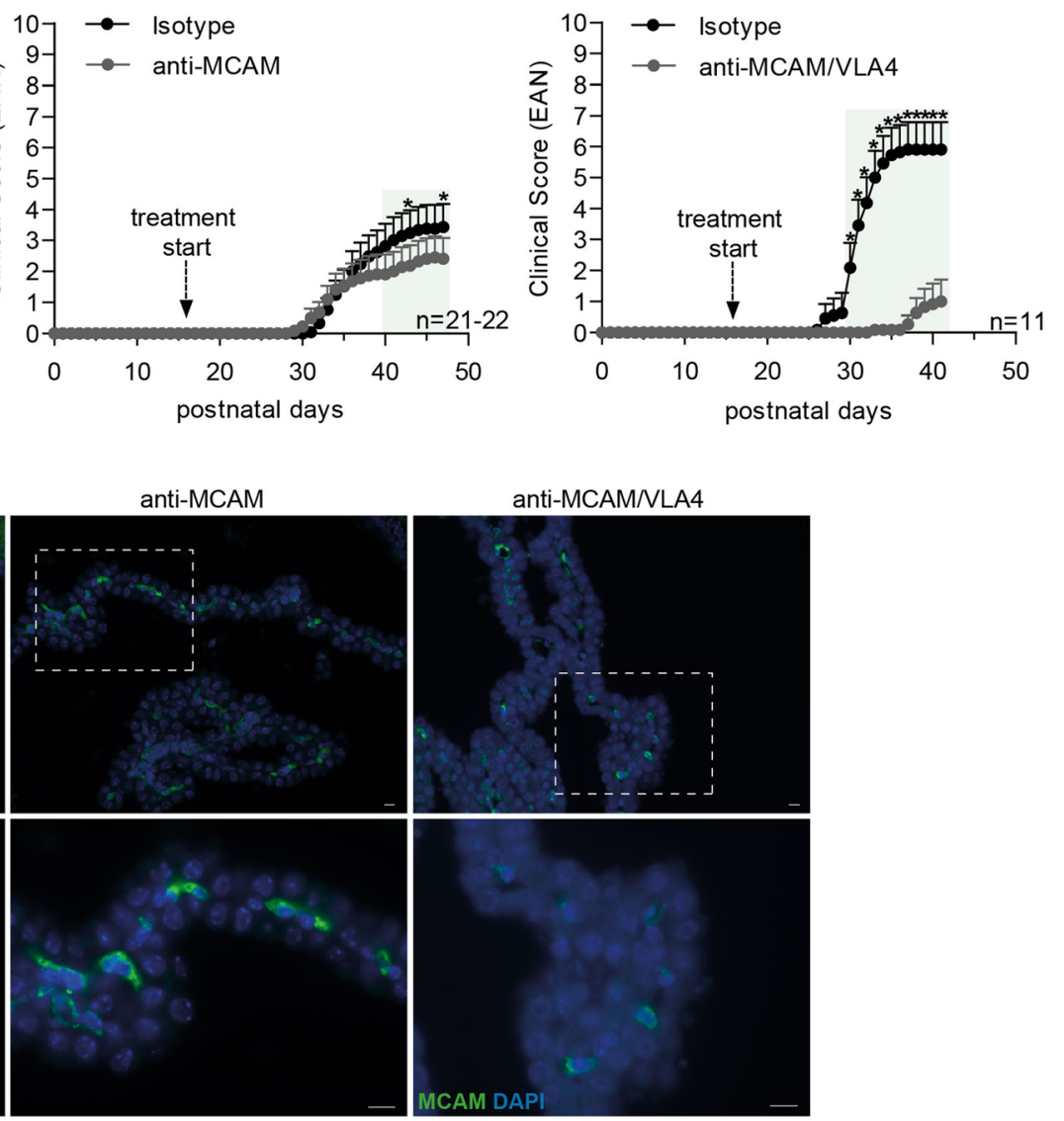

Fig. 2 MCAM and VLA4 blockade in a model of spontaneous EAE. Development of spontaneous EAE-like disease in Devic mice that were either treated with (a) anti-VLA4 (clone PS/2), (b) anti-MCAM (clone 15), (c) anti-MCAM and anti-VLA4 antibodies, or the respective isotype control antibodies. Mice were treated every second day from day 16 after birth. Littermates were used for the treatment with either the respective blocking antibody or the isotype control. Mean clinical EAN scores \pm SEM of three independent experiments over time are shown; ${ }^{*} P<0.05 ;$ green highlighted areas: $P<0.1$. (d) Immunofluorescence staining of MCAM (green) in choroid plexus tissue obtained from Devic mice treated with anti-VLA-4, anti-MCAM, or antiMCAMNLA-4 neutralizing antibodies. Nuclear staining (DAPI) is shown in blue. Scale bars are $10 \mu \mathrm{m}$

recipient mice. Immunofluorescence staining of cortical explants at days 2 and 5 after transfer revealed individual MCAM expressing $\mathrm{CD} 4^{+} \mathrm{T}$ cells in the $\mathrm{CP}$, providing first evidence that MCAM-expressing $\mathrm{T}$ cells can migrate through the $\mathrm{CP}$ and potentially into the CNS (Representative images are shown in Additional file 2: Figure S2; numbers of transferred cells, that were detected in the CP: mouse 1: 23; mouse 2: 19; mouse 3: 17). Staining of laminin $\alpha 4$ in cortical explants confirmed further the localization of the MCAM ligand to endothelial basement membranes of the CP (Fig. 3c-e).

\section{Enhanced migration of human MCAM-expressing T cells across endothelial and extracellular matrix barriers is dependent on MCAM-laminin 411 interactions}

To further investigate whether MCAM has an effect on lymphocyte migration over CP endothelial barriers, we performed in vitro $\mathrm{T}$ cell transmigration assays using primary human brain-derived microvascular endothelial cells (HBMECs) and choroid plexus fibroblasts (labeled as "HCPEpiC") (characterization of the cells is shown in Additional file 3: Figure S3). We have previously shown that laminin $\alpha 4$ can be expressed by fibroblasts in different tissues but is deposited in subjacent endothelial basement membranes [27] and that it is also expressed by cultured HBMECs [17]. Immunofluorescent staining confirmed that laminin $\alpha 4$ is present on cultured HCPEpiC-derived fibroblasts in vitro (Fig. 4a), and MCAM blockade indeed restricted transmigration of MCAM-expressing $\mathrm{T}$ cells (Fig. 4b). The proportion of $\mathrm{MCAM}^{+}$cells among $\mathrm{CD} 4^{+} \mathrm{T}$ cells was enriched in the fraction of cells that transmigrated the HCPEpiC-derived fibroblasts layer, compared to the initial (ex vivo) $\mathrm{CD} 4^{+} \mathrm{T}$ cell fraction, but was significantly reduced when the $\mathrm{CD}^{+}$lymphocytes were pre-incubated with a MCAM blocking antibody, either alone or together with anti-VLA-4. Moreover, analysis of 


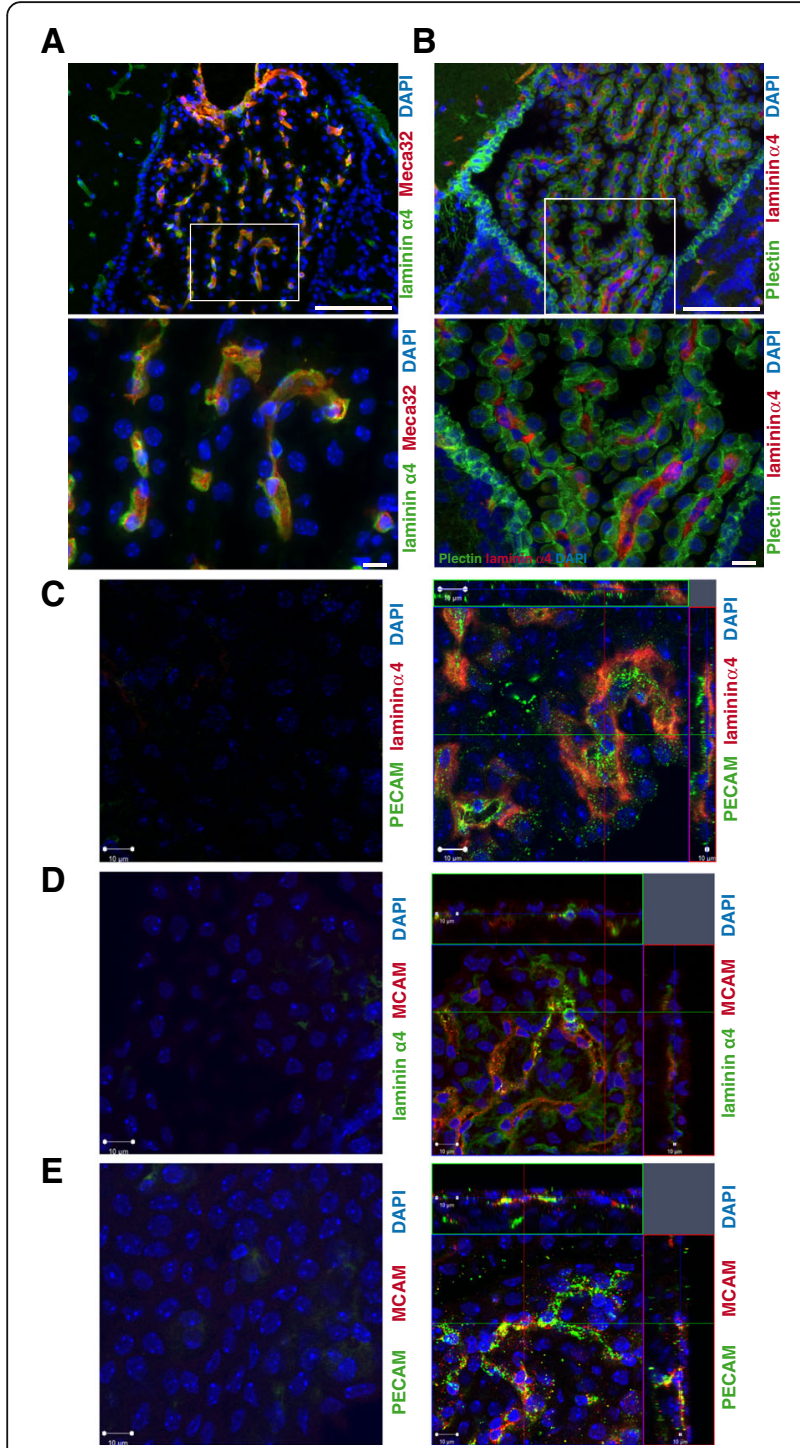

Fig. 3 Laminin a4 localization to choroid plexus endothelial basement membranes. C57BL/6 mouse choroid plexus samples immunofluorescently stained for (a) laminin a4 (green) and MECA32 antigen as an endothelial cell marker (red) or (b) laminin a4 (red) and plectin to mark choroid epithelium (green), demonstrating colocalization of laminin a4 with the MECA32 ${ }^{+}$blood vessels located beneath the epithelial layers. Cell nuclei are counterstained with DAPI (blue). Higher magnifications of the boxed areas are shown in the lower panels. Bars are $100 \mu \mathrm{m}$ (upper panels) and $10 \mu \mathrm{m}$ (lower panels), respectively. c-e Immunofluorescence staining of choroid plexus explants of C57BL/6 mice for (c) laminin a4 (red) and PECAM (green), (d) laminin a4 (green) and MCAM (red), and (e) PECAM (green) and MCAM (red). Nuclear staining (DAPI) is shown in blue, and left panels represent control stainings. Scale bars: $10 \mu \mathrm{m}$

fibroblastic layer following the transmigration period, revealed enrichment of $\mathrm{MCAM}^{+} \mathrm{CD}^{+} \mathrm{T}$ cells within the cell layer (Fig. 4c), suggesting adherence of $\mathrm{MCAM}^{+}$lymphocytes to laminin $\alpha 4$ in the deposited extracellular matrix during their migration through the cell layer. MCAM blockade led to marked accumulation of $\mathrm{MCAM}^{+}$
$\mathrm{CD}^{+}{ }^{+} \mathrm{T}$ cells within the cell layer (Fig. 4c), suggesting that the cells can still adhere to the fibroblastic cell layer, but require MCAM-mediated processes for efficient transmigration. This was substantiated by the results of transmigration over both TNF- $\alpha$ inflamed or non-inflamed HBMECs, which also revealed reduced $\mathrm{MCAM}^{+} \mathrm{CD}^{+} \mathrm{T}$ cell transmigration over an endothelial layer in presence of a MCAM blocking antibody (Fig. 4d).

To determine whether these in vitro findings are also relevant to the human in vivo system, we stained human CP tissue from one MS patient for laminin $\alpha 4$. We detected high laminin $\alpha 4$ expression in association with the endothelial layer of the CP, whereas no laminin $\alpha 4$ staining was detectable on the epithelial layer (Fig. 4e). The pattern of laminin $\alpha 4$ localization, therefore, supports the hypothesis that MCAM-laminin $\alpha 4$ interactions facilitate $\mathrm{MCAM}^{+} \mathrm{CD} 4^{+} \mathrm{T}$ cell penetration of the $\mathrm{CP}$ endothelial layer and thereby entry into the CNS during neuro-inflammation.

The differential effects of blocking VLA-4 and/or MCAM in active EAE and in the spontaneous EAE model suggest that targeting VLA-4 restricts most encephalitogenic $\mathrm{T}$ cells from migrating into the CNS, while blockade of MCAM more specifically inhibits $\mathrm{T}_{\mathrm{H}} 17$ cell migration into the $\mathrm{CNS}$ via the $\mathrm{CP}$ endothelium. Effects of MCAM blockade are particularly pronounced in murine models of MS that depend on CNS migration across the $\mathrm{CP}$, such as in the case of mice lacking $\alpha 4$-integrin expression on $\mathrm{T}$ cell. This is in accordance with our previous observation of a specific accumulation of $\mathrm{MCAM}^{+} \mathrm{CD}^{+}{ }^{+} \mathrm{T}$ cells in the CSF of MS patients with long-term Natalizumab therapy (VLA-4 blockade) [17], suggesting that $\mathrm{MCAM}^{+} \mathrm{CD}^{+}$lymphocytes preferentially migrate over the $\mathrm{CP}$ into the CNS. This may be further enhanced by the high expression of the chemokine receptor CCR6, a characteristic marker of the encephalitogenic $\mathrm{T}_{\mathrm{H}} 17$ cells [10], which binds to CCL20 expressed on the choroid plexus epithelium in mice [45] and confirmed here for human tissue (see Additional file 4: Figure S4).

Leukocytes that are recruited to the $\mathrm{CP}$ and thereby into the CNS have to migrate through the endothelium and underlying basement membrane before they can migrate through the epithelial barrier into the CSF. Here, we show that MCAM is required for migration of an encephalitogenic $\mathrm{MCAM}^{+} \mathrm{CD}^{+}$subpopulation of $\mathrm{T}$ cells into the $\mathrm{CP}$, as cells without MCAM showed reduced migration across both endothelial and fibroblastic laminin 411 expressing layers in vitro and reduced CNS infiltration in vivo.

Accordingly, laminin $\alpha 4$ was localized to basement membranes underlying the choroidal endothelium, but not choroidal epithelium, suggesting that MCAM-laminin 411 interactions mediate the initial choroidal endothelium 


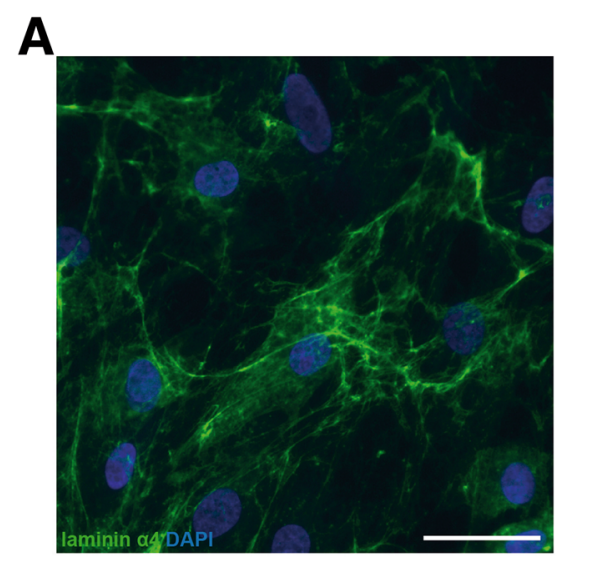

\section{B}
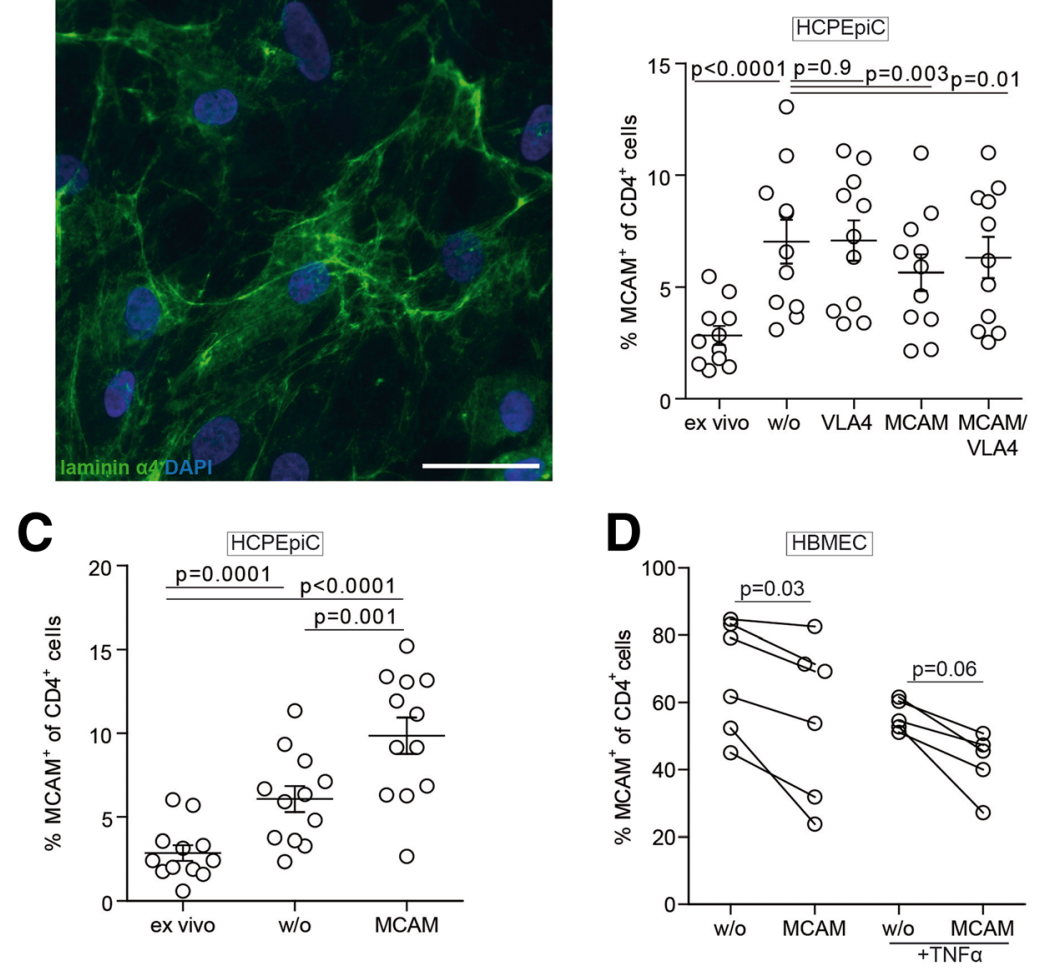

E

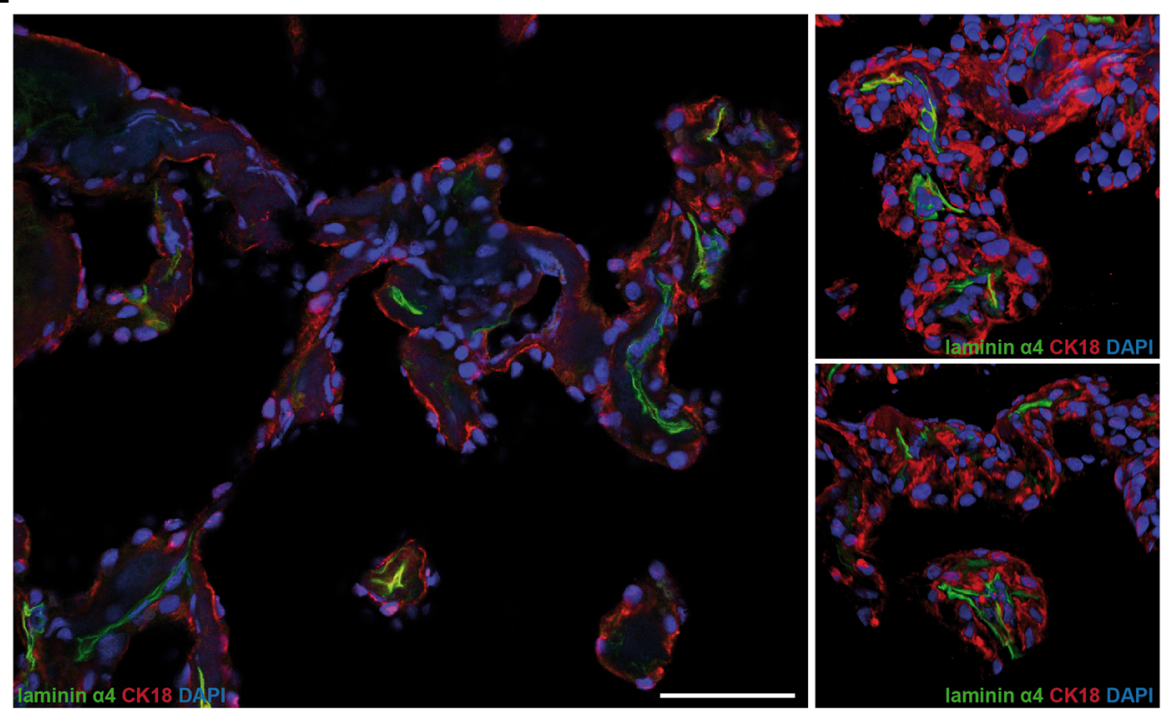

Fig. 4 MCAM-laminin a4 interactions mediate lymphocyte transmigration across human endothelial and fibroblastic layers. a Immunofluorescence staining of cultured fibroblasts derived from primary human choroid plexus cells (HCPEpiC) with anti-laminin a4 (green); cell nuclei are counterstained with DAPI (blue). Bar is $50 \mu \mathrm{m}$. b In vitro transmigration of CD4 $4^{+}$lymphocytes through the fibroblastic plus connective tissue layer in a modified Boyden chamber assay. Shown are the percentages of $\mathrm{MCAM}^{+} \mathrm{CD} 4^{+} \mathrm{T}$ cells before inclusion in the transmigration assay (ex vivo) and after transmigration without (w/O) blocking antibody or with VLA4, MCAM, or MCAM and VLA4 blocking antibodies. Data are from four independent experiments. $\mathbf{c}$ Percentages of $\mathrm{MCAM}^{+} \mathrm{CD}^{+} \mathrm{T}$ cells retained in the HCPEpiC layer in the absence (w/o) or presence of MCAM blocking antibody compared to the original sample (ex vivo). Data are from four independent experiments. $\mathbf{d}$ Percentages of $\mathrm{MCAM}^{+} \mathrm{CD} 4^{+} \mathrm{T}$ cells before and after transmigration of a HBMEC layer without (w/o) blocking antibody or with MCAM blocking antibody, under non-inflamed or inflammatory conditions (+TNFa). Data are from three independent experiments. e Laminin a4 (green) staining of human choroid plexus tissue from MS CNS samples. Nuclear staining (DAPI) is shown in blue, and the epithelial cell marker cytokeratin 18 (CK18) is shown in red. Bar is $50 \mu m$ 
crossing in vivo. The differential expression of laminin isoforms as a "doorway" for leukocyte migration across endothelial of post-capillary venules in the CNS parenchyma has previously been reported [34, 46, 47] and, therefore, a similar concept might also apply for the choroidal endothelium.

Importantly, by interfering with migration over the $\mathrm{CP}$ endothelium, MCAM blockade might have a specific effect on disease initiation. Others have previously reported the $\mathrm{CP}$ as the site of $\mathrm{T}$ cell entry into the CNS during immune surveillance and at first stages of neuro-inflammation [10].

However, besides the $\mathrm{CP}$, there are other entry routes into the CNS, such as through the circumventricular organs or through the leptomeninges, both of which are widely considered to be important in acute inflammation and perpetuation of CNS disease. In a rat EAE model, the leptomeninges was recently identified as an important checkpoint for $\mathrm{T}$ cell infiltration of the CNS, where effector $\mathrm{T}$ cells can enter the CSF and eventually invade the parenchyma [48]. These alternative entry routes into the CNS, which were not assessed in this study, might be the reason why a complete prevention of autoimmune CNS inflammation upon MCAM blockade in the absence of VLA-4 was not be observed.

\section{Conclusions}

Our results indicate that targeting MCAM results in an overall lower, but more specific clinical improvement compared to targeting VLA-4 and seems to affect mainly $\mathrm{T}_{\mathrm{H}} 17$ cells. This suggests that therapeutic blocking of MCAM might be advantageous over VLA-4 blocking, in terms of the balance of blocking pathogenic cells versus immune surveillance mechanisms and may, therefore, have fewer adverse effects. Hence, in case of a clear $\mathrm{T}_{\mathrm{H}} 17$ pathology, blocking of MCAM, instead or in addition, to VLA-4 or basic therapies such as anti-interferon treatment might represent a new therapeutic avenue.

\section{Additional files}

Additional file 1: Figure S1. MCAM expression on NK cells does not correlate with clinical score. Percentages of MCAM-expressing NK1.1 ${ }^{+}$ cells (a) isolated from the spleen, blood, spinal cord, and brain of isotype control or anti-MCAM-treated mice were quantified by flow cytometry on day 22 post $\mathrm{MOG}_{35-55}$ immunization. Correlation analyses between the clinical score (EAN) and percentages of MCAM-expressing NK1.1 $1^{+}$cells (b) in brains of isotype control (black dots) and anti-MCAM-treated mice (gray dots) on day 22 post immunization show no correlation for $\mathrm{NK}_{1.1^{+}}$cells (Spearman $r=-0.4427$; n.S.). (JPG $1119 \mathrm{~kb}$ )

Additional file 2: Figure S2. MCAM-expressing $C D 4^{+} \mathrm{T}$ cell migrate through the choroid plexus into the CNS. Representative images of adoptively transferred myelin oligodendrocyte glycoprotein-specific TCR-transgenic T cells (2D2 T cells) in whole-mount murine choroid plexus samples. 2D2 T cells were differentiated in vitro for 5 days under MCAM polarizing conditions $\left(\mathrm{MOG}_{35-55}, \mathrm{TGF} \beta, \mathrm{IL}-23\right)$, CMFDA-labeled, and transferred by i.v. injection to three $\mathrm{C} 57 \mathrm{BL} / 6$ recipient mice.
Immunofluorescence staining of choroid plexus explants on day 2 (mouse $1 ; \mathbf{a}$ ) and day 5 (mouse 2,$3 ; \mathbf{b}, \mathbf{c}$ ) after adoptive transfer for $\mathrm{CMFDA}^{+} \mathrm{CD}^{+} \mathrm{T}$ cells (green), and nuclei (blue; DAPI). Scale bars: $10 \mu \mathrm{m}$. (TIF $913 \mathrm{~kb}$ )

Additional file 3: Figure S3. Characterization of human brain-derived microvascular endothelial cells and fibroblasts derived from human choroid plexus cells. mRNA levels of laminin a4, cytokeratin 18 (CK18), PECAM1, VE-cadherin, and vimentin in primary human brain-derived microvascular endothelial cells (HBMEC) and fibroblasts originated from primary human choroid plexus epithelial cells (labeled as HCPEpiC) were quantified by real-time PCR, revealing the lack of epithelial markers by HCPEpiC and confirming their fibroblastic nature. n.d. = not detected (TIF $4578 \mathrm{~kb})$

Additional file 4: Figure S4. CCL20 localization on human choroid plexus tissue. CCL20 staining (green) on human choroid plexus epithelium in control CNS tissue samples. Nuclear staining (DAPI) is shown in blue. Scale bars $=100 \mu \mathrm{m}$. (TIF $6336 \mathrm{~kb}$ )

\section{Abbreviations}

BBB: Blood-brain barrier; CNS: Central nervous system; CP: Choroid plexus; CSF: Cerebrospinal fluid; EAE: Experimental autoimmune encephalomyelitis; HBMECs: Human brain-derived microvascular endothelial cells; HCPEpiC: Human choroid plexus epithelial cells; ICAM-1: Intercellular adhesion molecule-1; LFA-1: Leukocyte function-associated molecule-1; MCAM: Melanoma cell adhesion molecule; MOG: Myelin oligocendrocyte glycoprotein; MS: Multiple sclerosis; NK: Natural killer; $T_{H}$ : T helper; VCAM-1: Vascular cell adhesion molecule-1; VLA-4: Very late antigen-4

\section{Acknowledgements}

We thank Petra Babucke, Barbara Meyring (Department of Neurology, Münster) and Claudia Kemming (Department of Neuropathology) for excellent technical assistance.

\section{Funding}

This study was funded by the German Research Foundation (DFG) Grant CRC128 Project B1 to NS and AZ, Project A09/A10/Z2 to HW, A07 to TKo, B07/Z02 to TKu, B03 to LS, Prothena Biosciences Inc., the Interdisziplinäre Zentrum für Klinische Forschung (IZKF) Münster (Wie3/009/16) to NS and HW, and the Kompetenznetz Multiple Sklerose (Competence Network for Multiple Sclerosis) funded by the Federal Ministry of Education and Research (FKZ 01Gl1308B 01Gl0907) to HW and ToKo. This work was partially supported by the DFG Cluster of Excellence EXE1003.

\section{Availability of data and materials}

All data generated or analyzed during this study are included in this published article. The datasets used and/or analyzed during the current study are also available from the corresponding author on reasonable request.

\section{Authors' contributions}

$J B, E K, M J H, T S H, J S, L Z$, and SH performed experiments and analyzed the data. NS, LS, KF, TKO, AZ, and HW conceived and designed the study. TKu contributed to the data acquisition and interpretation. JB, LS, and NS wrote the manuscript. All authors read and approved the final manuscript.

\section{Ethics approval and consent to participate}

All animal procedures were approved by and conducted in accordance with the laws and the regulations of the regulatory authorities for animal care and scientific use in North Rhine-Westphalia, Germany. Studies on human samples were approved by the local ethics committee and performed according to the Declaration of Helsinki.

\section{Consent for publication}

Not applicable.

\section{Competing interests}

JB, EK, MJH, TSH, JS, LZ, SH, TKo, AZ, and LS have nothing to declare. KF is an employee of Prothena Biosciences Inc. TKu has received honoraria from Novartis and EXCEMED. HW has received honoraria and consultation fees from Biogen. NS has received travel support from Sanofi-Genzyme and Novartis. 


\section{Publisher's Note}

Springer Nature remains neutral with regard to jurisdictional claims in published maps and institutional affiliations.

\begin{abstract}
Author details
${ }^{1}$ Clinic of Neurology with Institute of Translational Neurology, University of Münster, Albert-Schweitzer-Campus-1, Building A01, 48149 Münster, Germany. ${ }^{2}$ Institute of Physiological Chemistry and of Pathobiochemistry, University of Münster, Münster, Germany. ${ }^{3}$ Cells-in-Motion Cluster of Excellence, University of Münster, Münster, Germany. ${ }^{4}$ Department of Anesthesiology, University of Münster, Münster, Germany. ${ }^{5}$ Prothena Biosciences Inc., South San Francisco, CA, USA. ${ }^{6}$ Department of Neurology, Technical University of Munich, Munich, Germany. ${ }^{7}$ Munich Cluster for Systems Neurology (SyNergy), Munich, Germany. ${ }^{8}$ Department of Neuropathology, University of Münster, Münster, Germany.
\end{abstract}

\section{Received: 28 March 2018 Accepted: 10 August 2018}

\section{Published online: 22 August 2018}

\section{References}

1. Alberio L, Dale GL. Review article: platelet-collagen interactions: membrane receptors and intracellular signalling pathways. Eur J Clin Investig. 1999;29: 1066-76.

2. Nylander A, Hafler DA. Multiple sclerosis. J Clin Invest. 2012;122:1180-8.

3. Dendrou CA, Fugger L, Friese MA. Immunopathology of multiple sclerosis. Nat Rev Immunol. 2015;15:545-58.

4. Frohman EM, Racke MK, Raine CS. Multiple sclerosis--the plaque and its pathogenesis. N Engl J Med. 2006;354:942-55.

5. Polman $\mathrm{CH}, \mathrm{O}^{\prime}$ Connor PW, Havrdova E, Hutchinson M, Kappos L, Miller DH, Phillips JT, Lublin FD, Giovannoni G, Wajgt A, et al. A randomized, placebocontrolled trial of natalizumab for relapsing multiple sclerosis. N Engl J Med. 2006;354:899-910.

6. Yednock TA, Cannon C, Fritz LC, Sanchez-Madrid F, Steinman L, Karin N. Prevention of experimental autoimmune encephalomyelitis by antibodies against alpha 4 beta 1 integrin. Nature. 1992;356:63-6.

7. Steiner O, Coisne C, Cecchelli R, Boscacci R, Deutsch U, Engelhardt B, Lyck R. Differential roles for endothelial ICAM-1, ICAM-2, and VCAM-1 in shearresistant T cell arrest, polarization, and directed crawling on blood-brain barrier endothelium. J Immunol. 2010;185:4846-55.

8. Klotz L, Burgdorf S, Dani I, Saijo K, Flossdorf J, Hucke S, Alferink J, Nowak N, Beyer M, Mayer G, et al. The nuclear receptor PPAR gamma selectively inhibits Th17 differentiation in a T cell-intrinsic fashion and suppresses CNS autoimmunity. J Exp Med. 2009;206:2079-89.

9. Korn T, Bettelli E, Oukka M, Kuchroo VK. IL-17 and Th17 cells. Annu Rev Immunol. 2009;27:485-517.

10. Reboldi A, Coisne C, Baumjohann D, Benvenuto F, Bottinelli D, Lira S, Uccelli A, Lanzavecchia A, Engelhardt B, Sallusto F. C-C chemokine receptor 6regulated entry of $\mathrm{TH}-17$ cells into the CNS through the choroid plexus is required for the initiation of EAE. Nat Immunol. 2009;10:514-23.

11. Glatigny S, Duhen R, Arbelaez C, Kumari S, Bettelli E. Integrin alpha L controls the homing of regulatory T cells during CNS autoimmunity in the absence of integrin alpha 4. Sci Rep. 2015;5:7834.

12. Rothhammer V, Heink S, Petermann F, Srivastava R, Claussen MC, Hemmer B, Korn T. Th17 lymphocytes traffic to the central nervous system independently of alpha4 integrin expression during EAE. J Exp Med. 2011; 208:2465-76.

13. Rothhammer V, Muschaweckh A, Gasteiger G, Petermann F, Heink S, Busch DH, Heikenwalder M, Hemmer B, Drexler I, Korn T. alpha4-integrins control viral meningoencephalitis through differential recruitment of T helper cell subsets. Acta Neuropathol Commun. 2014;2:27.

14. Engelhardt B, Ransohoff RM. Capture, crawl, cross: the T cell code to breach the blood-brain barriers. Trends Immunol. 2012;33:579-89.

15. Engelhardt B, Sorokin L. The blood-brain and the blood-cerebrospinal fluid barriers: function and dysfunction. Semin Immunopathol. 2009;31:497-511.

16. Wilson EH, Weninger W, Hunter CA. Trafficking of immune cells in the central nervous system. J Clin Invest. 2010;120:1368-79.

17. Schneider-Hohendorf T, Rossaint J, Mohan H, Boning D, Breuer J, Kuhlmann T, Gross CC, Flanagan K, Sorokin L, Vestweber D, et al. VLA-4 blockade promotes differential routes into human CNS involving PSGL-1 rolling of T cells and MCAM-adhesion of TH17 cells. J Exp Med. 2014;211:1833-46.
18. Dagur PK, McCoy JP Jr. Endothelial-binding, proinflammatory T cells identified by MCAM (CD146) expression: characterization and role in human autoimmune diseases. Autoimmun Rev. 2015;14:415-22.

19. Brucklacher-Waldert V, Stuerner K, Kolster M, Wolthausen J, Tolosa E. Phenotypical and functional characterization of Thelper 17 cells in multiple sclerosis. Brain. 2009;132:3329-41.

20. Dagur PK, Biancotto A, Stansky E, Sen HN, Nussenblatt RB, McCoy JP. Secretion of interleukin-17 by CD8+ T cells expressing CD146 (MCAM). Clin Immunol. 2014;152:36-47.

21. Dagur PK, Biancotto A, Wei L, Sen HN, Yao M, Strober W, Nussenblatt RB, McCoy JP Jr. MCAM-expressing CD4(+) T cells in peripheral blood secrete IL-17A and are significantly elevated in inflammatory autoimmune diseases. J Autoimmun. 2011;37:319-27.

22. Flanagan K, Fitzgerald K, Baker J, Regnstrom K, Gardai S, Bard F, Mocci S, Seto P, You M, Larochelle C, et al. Laminin-411 is a vascular ligand for MCAM and facilitates TH17 cell entry into the CNS. PLoS One. 2012; 7:e40443

23. Larochelle C, Cayrol R, Kebir H, Alvarez Jl, Lecuyer MA, Ifergan I, Viel E, Bourbonniere L, Beauseigle D, Terouz S, et al. Melanoma cell adhesion molecule identifies encephalitogenic T lymphocytes and promotes their recruitment to the central nervous system. Brain. 2012;135:2906-24.

24. Larochelle C, Lecuyer MA, Alvarez JI, Charabati M, Saint-Laurent O, Ghannam S, Kebir H, Flanagan K, Yednock T, Duquette P, et al. Melanoma cell adhesion molecule-positive CD8 T lymphocytes mediate central nervous system inflammation. Ann Neurol. 2015;78:39-53.

25. Larochelle C, Alvarez JI, Prat A. How do immune cells overcome the blood-brain barrier in multiple sclerosis? FEBS Lett. 2011;585:3770-80.

26. Duan H, Xing S, Luo Y, Feng L, Gramaglia I, Zhang Y, Lu D, Zeng Q, Fan K, Feng J, et al. Targeting endothelial CD146 attenuates neuroinflammation by limiting lymphocyte extravasation to the CNS. Sci Rep. 2013;3:1687.

27. Frieser M, Nockel H, Pausch F, Roder C, Hahn A, Deutzmann R, Sorokin LM. Cloning of the mouse laminin alpha 4 cDNA. Expression in a subset of endothelium. Eur J Biochem. 1997;246:727-35.

28. Scott LM, Priestley GV, Papayannopoulou T. Deletion of alpha4 integrins from adult hematopoietic cells reveals roles in homeostasis, regeneration, and homing. Mol Cell Biol. 2003;23:9349-60.

29. Bettelli E, Pagany M, Weiner HL, Linington C, Sobel RA, Kuchroo VK. Myelin oligodendrocyte glycoprotein-specific T cell receptor transgenic mice develop spontaneous autoimmune optic neuritis. J Exp Med. 2003;197: 1073-81.

30. Litzenburger T, Fassler R, Bauer J, Lassmann H, Linington C, Wekerle H, Iglesias A. B lymphocytes producing demyelinating autoantibodies: development and function in gene-targeted transgenic mice. J Exp Med. 1998;188:169-80.

31. Bettelli E, Baeten D, Jager A, Sobel RA, Kuchroo VK. Myelin oligodendrocyte glycoprotein-specific T and B cells cooperate to induce a Devic-like disease in mice. J Clin Invest. 2006;116:2393-402.

32. Krishnamoorthy G, Lassmann H, Wekerle H, Holz A. Spontaneous opticospinal encephalomyelitis in a double-transgenic mouse model of autoimmune T cell/B cell cooperation. J Clin Invest. 2006;116:2385-92.

33. Breuer J, Schwab N, Schneider-Hohendorf T, Marziniak M, Mohan H, Bhatia U, Gross CC, Clausen BE, Weishaupt C, Luger TA, et al. Ultraviolet B light attenuates the systemic immune response in central nervous system autoimmunity. Ann Neurol. 2014;75:739-58.

34. Sixt M, Engelhardt B, Pausch F, Hallmann R, Wendler O, Sorokin LM. Endothelial cell laminin isoforms, laminins 8 and 10, play decisive roles in T cell recruitment across the blood-brain barrier in experimental autoimmune encephalomyelitis. J Cell Biol. 2001;153:933-46.

35. Breuer J, Herich S, Schneider-Hohendorf T, Chasan Al, Wettschureck N, Gross CC, Loser K, Zarbock A, Roth J, Klotz L, et al. Dual action by fumaric acid esters synergistically reduces adhesion to human endothelium. Mult Scler. 2017:1352458517735189. https://doi.org/10. $1177 / 1352458517735189$

36. Schneider-Hohendorf T, Stenner MP, Weidenfeller C, Zozulya AL, Simon OJ, Schwab N, Wiendl H. Regulatory T cells exhibit enhanced migratory characteristics, a feature impaired in patients with multiple sclerosis. Eur J Immunol. 2010;40:3581-90.

37. Ringelmann B, Roder C, Hallmann R, Maley M, Davies M, Grounds M, Sorokin L. Expression of laminin alpha1, alpha2, alpha4, and alpha5 chains, fibronectin, and tenascin-C in skeletal muscle of dystrophic 129ReJ dy/dy mice. Exp Cell Res. 1999; 246:165-82. 
38. Hallmann R, Mayer DN, Berg EL, Broermann R, Butcher EC. Novel mouse endothelial cell surface marker is suppressed during differentiation of the blood brain barrier. Dev Dyn. 1995;202:325-32.

39. Korpos E, Kadri N, Kappelhoff R, Wegner J, Overall CM, Weber E, Holmberg $D$, Cardell S, Sorokin L. The peri-islet basement membrane, a barrier to infiltrating leukocytes in type 1 diabetes in mouse and human. Diabetes. 2013;62:531-42

40. Despoix N, Walzer T, Jouve N, Blot-Chabaud M, Bardin N, Paul P, Lyonnet L, Vivier E, Dignat-George F, Vely F. Mouse CD146/MCAM is a marker of natural killer cell maturation. Eur J Immunol. 2008;38:2855-64.

41. Stromnes IM, Goverman JM. Active induction of experimental allergic encephalomyelitis. Nat Protoc. 2006;1:1810-9.

42. Ransohoff RM. A mighty mouse: building a better model of multiple sclerosis. J Clin Invest. 2006;116:2313-6.

43. Agrawal S, Anderson P, Durbeej M, van Rooijen N, Ivars F, Opdenakker G, Sorokin LM. Dystroglycan is selectively cleaved at the parenchymal basement membrane at sites of leukocyte extravasation in experimental autoimmune encephalomyelitis. J Exp Med. 2006;203:1007-19.

44. Song J, Wu C, Korpos E, Zhang X, Agrawal SM, Wang Y, Faber C, Schafers M, Korner H, Opdenakker G, et al. Focal MMP-2 and MMP-9 activity at the blood-brain barrier promotes chemokine-induced leukocyte migration. Cell Rep. 2015:10:1040-54.

45. Zhang X, Wu C, Song J, Gotte M, Sorokin L. Syndecan-1, a cell surface proteoglycan, negatively regulates initial leukocyte recruitment to the brain across the choroid plexus in murine experimental autoimmune encephalomyelitis. J Immunol. 2013;191:4551-61.

46. Song J, Zhang X, Buscher K, Wang Y, Wang H, Di Russo J, Li L, Lutke-Enking S, Zarbock A, Stadtmann A, et al. Endothelial basement membrane laminin 511 contributes to endothelial junctional tightness and thereby inhibits leukocyte transmigration. Cell Rep. 2017;18:1256-69.

47. Wu C, Ivars F, Anderson P, Hallmann R, Vestweber D, Nilsson P, Robenek H, Tryggvason K, Song J, Korpos E, et al. Endothelial basement membrane laminin alpha5 selectively inhibits T lymphocyte extravasation into the brain. Nat Med. 2009;15:519-27.

48. Schlager C, Korner H, Krueger M, Vidoli S, Haberl M, Mielke D, Brylla E, Issekutz T, Cabanas C, Nelson PJ, et al. Effector T-cell trafficking between the leptomeninges and the cerebrospinal fluid. Nature. 2016;530:349-53.

Ready to submit your research? Choose BMC and benefit from:

- fast, convenient online submission

- thorough peer review by experienced researchers in your field

- rapid publication on acceptance

- support for research data, including large and complex data types

- gold Open Access which fosters wider collaboration and increased citations

- maximum visibility for your research: over $100 \mathrm{M}$ website views per year

At $\mathrm{BMC}$, research is always in progress.

Learn more biomedcentral.com/submissions 